Sławomir Sikora

ORCID: https://orcid.org/0000-0002-2147-8543

Institute of Ethnology and Cultural Anthropology

University of Warsaw

\title{
Feeling at home in Grochów. The phenomenon of Kicia Kocia
}

\section{Zadomowienie na Grochowie. Fenomen Kici Koci}

\begin{abstract}
Feeling at home can be metaphorically associated with dwelling (M. Heidegger) and finding/constructing one's place. With, i.a. the concepts of Heidegger and M. de Certeau as a starting point the author shows how the process of creating one's place can be understood today. Recalling various examples of tamed "places/venues" (the cigar shop in Smoke by P. Auster and W. Wang, the local shop in the anthropological documentary Tobacco, Trutbs and Rummikub by S. Meyknecht, and the "mobile bar" in Ankara described by D. Altay), he creates an ambiguous concept of the "own place today". An example crucial for the presented reflections is the establishment and functioning of the Kicia Kocia clubhouse in the district of Grochów (Warsaw) showing how a "real place" can be created first virtually (Facebook), through stories and things, and then by the people themselves or rather through their relationships. It is the latter - or their network that allow to construct a place-rhizome, which radiates throughout a district.
\end{abstract}

Keywords: anthropology of space, Kicia Kocia clubhouse, feeling at home, Grochów, place, urban anthropology

Zadomowienie można metaforycznie wiązać z zamieszkiwaniem (M. Heidegger) i odnajdywaniem/konstruowaniem własnego miejsca. Wychodząc m.in. od koncepcji Heideggera i M. de Certeau, autor pokazuje, jak może w dzisiejszych czasach wyglądać proces tworzenia własnego miejsca. Przywołując różne przykłady oswojonych „miejsc/lokali” (tawerna w Dymie P. Austera i W. Wanga, lokalny sklepik w antropologicznym filmie Tobacco, Truths and Rummikub S. Meyknechta, „ruchomy bar” w Ankarze opisany przez D. Altaya), autor konstruuje niejednoznaczną koncepcję „własnego miejsca dziś”. Kluczowy dla rozważań przykład to tworzenie i funkcjonowanie klubokawiarni Kicia Kocia na warszawskim Grochowie. Pokazuje on, jak „realne miejsce” może być tworzone zrazu wirtualnie (Facebook), dzięki opowieściom i rzeczom, 
a następnie dzięki samym ludziom, czy też relacjom, jakie oni nawiązują ze sobą. To ci ostatni - czy też sieć relacji - pozwalają na zbudowanie miejsca-kłącza, promieniującego na całą dzielnicę.

Słowa kluczowe: antropologia miasta, antropologia przestrzeni, Grochów, klubokawiarnia Kicia Kocia, miejsce, zadomowienie

Odebrano / Received: 31.01.2019

Zaakceptowano / Accepted: 27.08.2019

The nature of building is letting dwell. Building accomplished its nature in the raising of location by the joining of their spaces.

Martin Heidegger

"Place" is one of the trickiest words in the English language, a suitcase so overfilled one can never shut the lid.

Dolores Hayden

[David] Harvey argues that the disorientation of present times is giving rise to a new - and in his view almost necessarily reactionary - search for stability through a sense of place.

Doreen Massey

One could start by asking about the present-day meaning of feeling at home. The Synonim.Net Internet dictionary (in Polish) reacted to a question about synonyms of the term: "feeling at home" (zadomowić się) with a whole gamut of words, including the expression: "to kill oneself". Naturally, I shall not delve into the manner in which this particular dictionary was created. Nonetheless, the entry also contained such words and expressions (which I cite with numerous omissions) as: to enroot oneself, to anchor oneself, to succumb to assimilation, to integrate oneself, to settle down, to establish oneself, to get set up, to ensconce oneself, to create a home, to nest, to start a family ${ }^{1}$.

We shall not discover the words: "to dwell" or "to reside" within this sequence of associations, both understandable and those giving rise to reservation. I maintain that it is precisely "to dwell" that in a Heidggerian dictionary could appear to be close to "feeling at home". At the very onset I shall thus take the liberty of a brief excursion - possibly overly burdened with quotations - in the direction of Martin Heidegger; I am concerned predominantly with evoking a number of significant references and not with turning the problem into a discourse. Within this context "place" too appears to be an important concept. Subsequently, I shall embark upon a number of examples in which,

1 https://synonim.net/synonim/zadomowi\%C4\%87+si\%C4\%99, 15 November 2018. 
I believe, places, their creation or "discovery" can be combined - at least metaphorically with feeling at home or its substitute, the feeling of familiarity, of being at home. These examples are close, although, at the same time, they originate from totally different spaces. Some are as real as possible, while others enter into the domain of so-called fiction, i.e. in this instance the feature film.

As I have mentioned, I shall start with Heidegger whom I regard as important because he paid attention to the meaning of the thing in dwelling and creating places. Right away I add that I would like to transgress this limitation to the thing.

Bauen, buan, bbu, beo are our word bin in the versions: ich bin, I am, du bist, you are (...). What then does ich bin mean? The old word bauen to which ich bin belongs, answers: ich bin, du bist mean: I dwell, you dwell. The way in which you are and I am, the manner in which we humans are on the earth, is Buan, dwelling. To be a human being means to be on the earth as a mortal. The old word bauen, which also says that man is insofar as he dwells, this word, however, also means at the same time to cherish and protect $(\ldots)^{2}$.

Heidegger strongly connected dwelling with being and protection but also precisely with a place. "But only something that is itself a location can make space for a site"

Pursuing this thought further Heidegger suggested, i.e. that things create places ${ }^{3}$. One of the key examples is the bridge. This is a special instance because, apparently, the bridge can be also deciphered as a figure of connection and conflictlessness. "The bridge lets the stream run its course and at the same time grants their way to mortals so that they may come and go from shore to shore", "a location comes into existence only by virtue of the bridge". Although there are numerous points along a river, according to Heidegger only building a bridge creates location (place). "Only things that are locations in this manner allow for spaces". "Man's relation to locations, and through locations to spaces, inheres in his dwelling" 4 . It is also worth remembering that Heidegger strongly opposed the concept of "empty space" and "empty place".

Assorted contemporary authors variously conceptualise questions of the relation between place and space, although, as a rule, they ascribe significance precisely to place.

$\mathrm{Yi}-\mathrm{Fu}$ Tuan linked it with security, stressing that it is a world of organised meanings. He associated space with freedom, but also with experience and danger. "Tamed", familiar space "has become place" . At the same time Tuan noticed that a thus understood place is deprived of dynamic, "is essentially a static concept".

2 Heidegger 2001, p. 145.

3 Unless marked otherwise all spaced out emphasis is mine (S. Sikora)

${ }^{4}$ Heidegger 2001, citations in this paragraph originate successively from pages: 151-153, 155.

5 Tuan 2001, p. 73.

Tuan 2001, p. 179. 
Michel de Certeau comprehended this question closely although not identically. For him the key concept was practice. One of the important methods in thinking about space became the aerial view (from the already non-extant World Trade Centre towers) as well as walking and the activity of people in space. De Certeau compared the act of walking to the act of speaking (speech act) ${ }^{7}$ and recognised the aerial view to be a semblance of knowledge. In doing so he acknowledged that the latter, associated with practice and activity, is knowledge proper, which, I believe, is close to ethnography. Until the act of speaking is not written down it is just as fleeting as the act of walking (on the city pavement, as a rule, it does not leave behind any traces). "Their intertwined paths give their shape to spaces. They weave places together (...) it is rather they that spatialize" The very act of walking alters space. "To walk - de Certeau noticed - is to lack a place. It is the indefinite process of being absent and in search of a proper" ${ }^{\prime \prime}$ Slightly further on he wrote:

On this view, in relation to place, space is like the word when it is spoken, that is, when it is caught in the ambiguity of an actualization, transformed into a term dependent upon many different conventions, situated as the act of a present (or of a time), and modified by the transformations caused by successive contexts. In contradistinction to the place it thus has none of the univocity or stability of a "proper".

In short, space is a practised place ${ }^{10}$.

At this stage it is worth referring to two concepts of importance for de Certeau: strategy and tactic. In his comprehension of the two he referred to Clausewitz, a classic of the art of war. Strategy is the domain of the strong while tactic is connected with the position of the weaker and is rather a method suitable for partisans. The latter (usually) do not have a place of their own and thanks to tactic and interception act in the space of

\footnotetext{
${ }^{7}$ Most clearly he borrowed it from Roland Barthes (1997; originally the presentation in French took place in 1967), who was more radical and maintained that this comparison of the steps made by man and acts of speech should be treated in a non-metaphorical manner. Unacquainted at the time with the above-mentioned essays by Barthes or de Certeau I admired the conceptions launched by John Berger and Jean Mohr, who in a photo-essay composed of over 150 photographs (unnumbered pages) compared on two adjoining pages, i.a. photographs of jumbled bird "traces" on snow and a child standing in front of a blackboard, learning to read French words split into syllables: "ro - ri - ru - ra - rame. / une rue - un mari - les rêves". For us the traces of birds' feet are a puzzle, but an adept forester would be probably capable of easily deciphering the sort birds they were, their number, etc. A child must learn the relation of speech and record, and understand that, e.g. in French some of the "e" remain mute. At the time I perceived in the configuration of those photographs an attempt at creating a metaphor (as understood by Paul Ricoeur) and evoking experience. Cf. Berger and Mohr 1982, Sikora 2004, pp. 151-154.

${ }^{8}$ De Certeau 1984, p. 97.

${ }^{9}$ De Certeau 1984, p. 103.

${ }^{10}$ De Certeau 1984, p. 117, emphasis in the original.
} 
the other, temporarily changing space "planned" (seized) by others. "I call a tactic calculated action determined by the absence of a proper locus. (...) The space of a tactic is the space of the other" ${ }^{11}$. While referring to a possibly overly simple example it could be said that the plan of streets and pavements is, as a rule, determined top-down by city authorities; nonetheless, the way in which pedestrians but also, e.g. skateboarders or people practicing parkour exploit and use it is already an entirely different matter. In my opinion the equation of the acts of walking (or more extensively: acting) with the acts of speaking, expressing, and, as a consequence, with narratives is of crucial importance ${ }^{12}$.

In further cited examples we shall find the role of the narrative in the creation of one's own place, but also more widely that of a district and a town.

Tim Ingold too draws attention to the importance of practice, activity, walking, and strolling. In addition, he speaks decisively against space comprehended as an abstract concept that "diverges" from practice (life). Here is his witty interpretation:

I wish to argue, in this chapter, against the notion of space. (...) Throughout history, whether as hunters and gatherers, farmers or herders of livestock, people have drawn a living from the land, not from space. Farmers plant their crops in the earth, not in space, and harvest them from fields, not from space. Their animals graze pastures, not space. Travellers make their way through the country, not through space, and as they walk or stand they plant their feet on the ground, not in space. Painters set up their easels in the landscape, not in space. When we are at home, we are indoors, not in space, and when we go outdoors we are in the open, not in space. Casting our eyes upwards, we see the sky, not space, and on a windy day we feel the air, not space. Space is nothing, and because it is nothing it cannot truly be inhabited at all ${ }^{13}$.

I recall once again - ending these theoretical approximations - the definition of a district proposed by Pierre Mayol, a close collaborator of de Certeau; a district is an area in which the residents find everything they need in their daily life: it is a "consequence of walking". "The neighbourhood is a dynamic notion requiring a progressive apprenticeship that grows with the repetition of the dweller's body's engagement in public space until it exercises a sort of appropriation of this space" ${ }^{14}$. This meeting of needs can be also recognised as a synonym of feeling at home - an open and, at the same time, precise definition. In latter citations the category of life, daily existence, and everyday practices comes to the foreground.

${ }^{11}$ De Certeau 1984, p. 37.

12 "Stories «go in a procession» ahead of social practices in order to open a field for them". De Certeau 1984, p. 125.

${ }^{13}$ Ingold 2011, p. 145.

${ }^{14}$ Mayol 1998, pp. 10-11, more widely: pp. 10-13. 
At this point I would like to consider the earlier announced examples of places, which literally and metaphorically are combined with dwelling and being at home, but also with the creation of "own places". Although such examples are close, similar and, simultaneously, dissimilar they evoke a certain form of feeling at home. They demonstrate how differently we may perceive space today. They also show that at present the place-space opposition cannot, or can no longer be comprehended as strong. I shall end with an example taken from Grochów, which is already linked with my research.

I shall begin by evoking the famous cigar shop managed by Auggie Wren in Brooklyn, which became one of the central places in Smoke, the film directed by Paul Auster and Wayne Wang (1995). This is where the roads of assorted people-acquaintances living in the vicinity cross. Here they sit, as a rule conducting trifling everyday conversations; sometimes these small talks turn into grander narratives and stories, but then they most often cover a wider space. We are dealing with a place evidently firmly enrooted in time and space. From the perspective of his street corner (crossing of 16th Street and Prospect Park West, Brooklyn) every day Auggie Wren takes photographs of surrounding reality, creates "life projects", documents that will contribute (as often in photography by chance!) to changing the life of the writer Paul Benjamin ${ }^{15}$. I shall not recount here the twists and turns of the film's plot, but I recall fragments of a conversation between the two lead protagonists: the writer Paul Benjamin and the black teenager who likes to change his name: Rashid, Thomas, Paul... This conversation clearly indicates the specificity of social space and its perception, which could be strongly individualised and linked with such factors as skin colour or social class. It takes place in the writer's apartment and is connected with the fact that the black boy accidentally witnessed a bank robbery; more, he recognised its perpetrators...

Rashid: ...You don't really want to know... (...) The man has friends. I don't think they're not likely to forgive me if I testify against him.

Paul Benjamin: What makes you think you'll be safer here? You're close to where you live.

Rashid: It's not that far away, but it's another galaxy. Black is black, and white is white and ne'er the twain shall meet.

Paul Benjamin: Well, it looks like they've met in this apartment.

Rashid: Let's not get too idealistic ${ }^{16}$.

${ }^{15}$ I wrote about this more extensively in my book on photography: Sikora 2004, pp. 183-197.

${ }^{16}$ Sound track from the film Smoke, P. Auster and W. Wang 1995. As if confirming the words of Rashid Sharon Zukin noticed: "But unlike hipster Williamsburg, black Brooklyn was dangerous". Zukin 2010, p. 57. In the book Naked City: the Death and Life of Authentic Urban Places (2010) Zukin outlined a brilliant history of the gentrification of Brooklyn (basically Williamsburg), showing how from the 1940s artists started arriving here after fleeing Manhattan. Brooklyn was cheaper but also started to be characteristic for an entirely different lifestyle and certain slowness. "Most people call this gentrification. But that is too narrow a term to describe the demographic and economic changes that have reshaped both Brooklyn's physical fabric and its reputation". Zukin 2010, p. 58. 
The dialogue shows clearly that social space and its perception possess numerous determinants.

Is the special form of feeling at home in Brooklyn, or, more broadly, in New York not described also by Lou Reed in a para-documentary sequel to Smoke, i.e. Blue in the Face (1995), made as if parallel by the same authors? Here Lou appears as himself standing behind the counter of another cigar shop, while his stories, even if created for the purpose of the film, assume the form of "true fantasies" associated with experiencing (mythologised and personalised) the world ${ }^{17}$. Naturally, Reed also plays with the public, in other words, us, the spectators of the film, but he also speaks about a specific paradoxical version of a contemporary feeling at home. Here, the security that Yi-Fu Tuan linked with the place (and feeling at home) has been reversed in a special way.

I'm scared in my own apartment. I'm scared 24 hours a day but not necessarily in New York. I actually feel pretty comfortable in New York. I get scared like in Sweden. You know, it's kind of empty, they're all drunk, and everything works. You know, if you stop at a stop and don't turn your engine off people come up and talk to you about it. You go to the medicine cabinet and open it up and there will be a little poster saying: in case of suicide - call... You turn on the TV - there's an ear operation. These things scare me. New York? No. ${ }^{18}$

An example of a "place" analogous to Auggie Wren's cigar shop can be discovered in Tobacco, Truths and Rummikub by Steef Meyknecht (2010), a film that could be described as an anthropological version of Smoke, similar but, at the same time, totally different. Naturally, in this instance we are dealing already with a totally real place or rather places. I am interested particularly in one aspect - a small neighbourhood store, which turned into a specific "club" for local young immigrants. For more than a year the Dutch anthropologist-filmmaker observed relations prevailing in one of the districts of Schiedam (in the Rotterdam metropolitan area). He even decided to live nearby so as to be on the spot. One of the prime locations he focused on was a small local shop in the district of Nieuwland, once a so-called good neighbourhood inhabited by the white middle class and today regarded by its former residents as dangerous due to the influx of immigrants from, for all practical purposes, every part of the world. The shop itself, ran by a young and, most likely, relatively new immigrant, became a meeting place mainly for young people of colour. It turned into their space, a substitute of feeling at home in this new world. One has to have a place of one's own - declare its habitués - one has to be capable of "finding" it. The presence in the shop of young people of colour, however, resulted in the "withdrawal" of former habitués from this space; they stopped frequenting

\footnotetext{
${ }^{17}$ It could be said that each person lives in his or her own (micro)cosmos. By way of example, for Barthes this was, i.a. the oeuvre of Proust (Barthes 1975, pp. 42-43). More on the cosmos cf. Hertzfeld 2004, pp. 269-299.

${ }^{18}$ Sound track from the film: Blue in the Face, P. Auster and W. Wang 1995.
} 
it and shopping; as a consequence, the agent became indebted and ultimately went bankrupt. Naturally, this is a more complicated story with an understated moral in the background ${ }^{19}$.

Meyknecht skilfully intermingled several narration motifs (but also confronted a number of places) speaking about the space of the district and not merely the shop-place. Apart from the shop the space in question includes a local club frequented primarily by female senior citizens from the district, a police station, a Moslem religious school for children of, as a rule, recent immigrants... We are thus dealing with an attempt at outlining a system of relations most often depicted thanks to stories and narrations. They indicate, i.a. mutual misunderstandings and disclose the absence of feeling secure, but also show stereotypes in the perception of others, which, as a consequence, result in the closeting of (predominantly) the group of former residents against incomers. Naturally, the film calls for a more thorough presentation. I would like to add only several words of the epilogue (the mentioned moral), which, unfortunately, did not become part of the film ${ }^{20}$. Apparently, after ending the montage Meyknecht decided to show the film to its protagonists - today, this is an expected anthropological practice. $\mathrm{He}$ invited them to a local cinema for a premiere. There, in the media space of the cinema they met as if for the first time personally, first via the movie screen and then face to face in the foyer, and became aware just how stereotyped and mythicized were the images of the neighbours that, as a rule, accompanied them (I stress that I am concerned primarily with the image of coloured neighbours prevalent among former white residents). As a consequence of this event the district authorities expressed their readiness to sponsor the shop in recognition of the fact that it played the positive part of a "club". Earlier, such suggestions had been made by the local police - without any response... The problem lies in the fact that this awareness emerged much too late and neither the former agent nor the young coloured people agreed to such a solution. Already in the film the latter protagonists spoke with a certain dose of bitterness about being forced to seek a new place.

A successive example was presented by Deniz Altay describing a "mobile bar" in Ankara in: Urban Spaces Re-Defined in Daily Practices - «Minibar», Ankara ${ }^{21}$. In the evenings young people started gathering near one of the main city streets where they found a place for regular meetings and conversations in informal groups. The street infrastruc-

${ }^{19}$ See: Sikora 2012, pp. 173-177.

${ }^{20}$ Oral information. Conversation with Meyknecht in Århus during the NAFA (Nordic Anthropological Film Association) film festival held in 2010. The film was also shown upon several occasions in Poland, i.a. at the time of the 35. NAFA Festival (Warsaw 2015). I believe that additional montage of this epilogue would enhance the film. In my opinion some sort of a breaking of the convention (Meyknecht, who unfortunately died in 2015, was an adherent of the observation cinema), would have by all means stood up for itself.

${ }^{21}$ Altay 2007. 
ture guaranteed a place to freely stand or sit in small groups. Alcohol came from nearby stores. When upon certain occasions the police appeared due to complaints made by the residents the "bar" moved to one of the adjoining streets. No one formalised these meetings. In time it became possible to create a consensus with the local residents. The bar habitués tried not to disturb the peace with their loud behaviour and to clean up after themselves. This is an excellent example that a place is essentially created by people or rather the relations between them. It is they who, together with their rhythmically recurring appearance, changed the status of the place. No one remembers how it all actually began ...

Comparable bottom-up initiatives of meetings can assume a different form and are to be discovered in numerous towns (on the Guadalquivir waterfront in Seville or along the banks of the Vistula in Warsaw). Another slightly similar place was described by Maciej Frąckowiak and Piotr Luczys ${ }^{22}$. An informal "club", which came into being in a waste ground in one of the districts of Poznan was created by local residents, who decided to occasionally gather there to spend some time and drink beer in each other's company. Camouflaged against incidental spectators and outfitted with old and no longer needed furniture it functioned by becoming a place of special asylum for local men and allowing them to jointly spend time in a non-formalised manner ${ }^{23}$.

The example from Ankara is an excellent illustration of the fact that places are, for all practical purposes, created by people and their mutual relations. Without them such a place would remain "empty" (or, to put it more correctly, would have been totally different); upon each occasion it was established by people owing to the very fact of their presence. I recall the remark made by Heidegger, namely, that only a bridge "creates" place. In earlier described instances places were created predominantly by people, together with their daily small talks and recounted stories.

In this respect, the last example, which I wish to cite, is exceptional: in a sense it also deals with changing the conception of the place and demonstrates how narrations are capable of creating a place, first virtually and then by applying all means in the real world. Narrations and Facebook, narrations on Facebook, but also in other media and in the so-called "real world". I have in mind the creation of the Kicia Kocia clubhouse. Together with Karolina Dudek we described this process in the book: Pustynia kulturalna? Siedem szkiców o dziataniu na Grochowie (Cultural Desert? Seven Pieces on Culture Making in Grochów, 2018). When I started writing the chapter dealing with Kicia Kocia ${ }^{24}$ I decid-

\footnotetext{
${ }^{22}$ Frąckowiak and Luczys 2012.

${ }^{23}$ Traditionally bars are associated with "male" space, although today this is decidedly not the rule. "The «neighbourhood café» - in contrast to the "passing-through café,» whose function is completely different - can in some ways be considered as the equivalent of the «men's club» of traditional societies". Mayol 1998, p. 24.

${ }^{24}$ We wrote each chapter jointly; nonetheless, one of us initiated it and then there followed an alternating stage of additions and editing. Naturally, we talked a lot about the conception of particular chapters.
} 
ed to read Facebook entries systematically and thoroughly. Naturally, we were both well acquainted with this place and for two years systematically spent some time there. We attended assorted meetings and events arranged by various subjects. We also took part in several walks organised or co-organised by Kicia Kocia. Nonetheless, only when I started to reread the Facebook account systematically did I become fully aware of the greatly interesting virtual manner of creating the place we were dealing with. Remember, all this occurred prior to the official opening of the venue.

The owner and initiator of the clubhouse ${ }^{25}$ - which at present has already changed its location and consequently slightly altered its profile - was, and is, Cezar Polak (who ran it together with Małgorzata Pilewska), journalist, expert on Warsaw, and aficionado of Grochów, although at the time he had been living there for not quite ten years. I shall deal only with a closed chapter in the existence of Kicia Kocia, a period when it was situated in a freestanding (and today non-existent) building of a former heating plant (5a Garibaldiego Street, Warsaw).

Originally, Polak started creating the "story" of Kicia Kocia on Facebook by writing about the progress of the work involved and struggles with assorted officials and administrative demands, albeit not only. Naturally, reading this account was a task much more entertaining than strenuous. From the very onset narrations created or "built" a place that became a social space-time (or perhaps time-space) vividly discernible in assorted Facebook entries. They genuinely built this place, i.e. created a group of interested readers and friends, who read, liked, and commented those entries and sometimes impatiently inquired about the club's final opening. Their posts also referred to the history of the district and People's Poland.

During the Gomulka and Gierek era the future seat of Kicia Kocia fulfilled the function of a plant heating water for a nearby housing estate. We are proud of the heritage. We too shall warm up this neighbourhood, although by slightly different means. The photograph [presented on Facebook] comes from the turn of the 1960s. It shows a view from Stanów Zjednoczonych Avenue, near the corner of Rondo Wiatraczna. The former site of a sledding hill today features pavilions, which the residents of Grochów call "Mushrooms". Do you remember this view?26 (Kicia Kocia profile, 12 November 2012)

Pay attention to the skilful inscription of the place (i.e. the venue) into history, including that of the People's Republic of Poland. This domestication of the place originally occurred conspicuously precisely via time. Such an attempt at becoming part of

${ }^{25}$ A clubhouse is somewhat more than a café, and this "more" was clearly visible in the activity of the venue.

${ }^{26}$ https://www.facebook.com/KlubKiciaKocia/photos/a.479813125373254.108938.458666394154 594/482193858468514/?type=3\&permPage=1,15 December 2015. 
tradition and the local quality (exactly in the temporal-spatial dimension) possessed assorted versions. Also on Facebook we come across entries concerning acquired furniture, often discovered or found, donated, and sometimes purchased, a hotchpotch maintained in the middle or late People's Poland style. Interaction with things started with descriptions-stories on Facebook. Photographs were also presented. Objects and stories about them co-created (at first only virtually) a certain climate and aura surrounding Kicia Kocia. One could say that we started to see before we looked. This place is, first of all, an awaited and imagined virtual place. Polak skilfully stirred imagination and wishes. There also appeared questions asking when the clubhouse would be finally opened ${ }^{27}$. Assorted acquisitions are accompanied by cleverly fashioned stories, co-created with a considerable dose of humour:

Kicia Kocia gave itself a Christmas present - or actually You too, because I hope that you will use it. In the Szmulki area (or more precisely in Grajewska Street) it purchased the presented piece of furniture: an object, which, it turned out, is extremely universal. Its counter can be easily raised and lowered with the help of a special lever with a winder. (...) It is varnished with a high gloss so that even on cloudy days it shines like... you know what. This bench-cum-table originates from the 1970s. We do not know the catalogue name of this piece of furniture or data concerning the designer and producer. ${ }^{28}$ (Facebook, 22 December 2012)

Naturally, this is not the only such piece of information from partly virtual reality. Insertion into history was connected also with references to the person of Miron Białoszewski ${ }^{29}$. Facebook presented the first fragments of the poet's portrait (a mural) painted on one of the walls (inside the building). This was a case of cleverly spicing up

${ }^{27}$ The response is immediate: "Thanks $)$ We have been making plans already for over a year. This is how long it took us to obtain assorted permits, because we changed the manner of using the spaces from laboratory-workshop to café. And since the area of Rondo Wiatraczna - just like the majority of areas in Warsaw and Poland - is devoid of a development plan we were compelled to commission expert opinions and the sort of elaborations that are mandatory for the construction of new buildings, and then we had to wait, wait and wait... Despite the fact that we pulled down only one and a half partition wall. We also had to meet all the prohibitive (supposed) Union norms and recommendations - the prime being guaranteeing parking space for the motorized public. And we did (-), which, in the case of clubs and cafés appears to be truly unusual. We also have, among others, suitably wide doors, ramps and toilet facilities for the handicapped as well as facilitations for parents with small children (naturally with big ones too). And for quadrupeds $:$ ". (Facebook, 14 December 2012 o 01:53). https://pl-pl.facebook.com/KlubKiciaKocia/photos/a.4 79813125373254.108938.458666394154594/498384776849422/?type=3, 15 December 2015.

${ }^{28}$ https://www.facebook.com/KlubKiciaKocia/photos/a.479813125373254.108938.4586663941545 94/497360890285144/?type= 3\&theatre, 15 December 2015.

${ }^{29}$ Halina Pfeffer-Oberländer, who Białoszewski called Kicia Kocia, was a Kicia Kocia Cabaret protagonist. Her portrait, similarly to the one of Frida Wołkowyska, shot during a robbery assault against the kibbutz (1935), found itself on the building façade. 
the mood and disclosing successive fragments of awaited (virtual) reality. Naturally, systemically added entries were accompanied by commentaries and likes. The interactive nature of the medium shows that we can speak about two-sided communication. It is worth nothing that in this instance the identity of the place is created thanks to things, just as in the case of Heidegger. Although they are not always the most important they appear together with stories and at first assume the form of a thing-narrative. Pieces of paper with the names of the donors, glued or affixed onto the furniture, and which in time sometimes fell off or were torn off, can be also recognised as a substitute of those things-narratives. Most clearly, things felt at home in the new place... losing their strong connection with former owners and places. But Facebook narratives did not come to a halt even when Kicia Kocia already welcomed guests. They accompanied and co-created successive planned events and parties. They also supplemented the culinary offer and, predominantly, the many brands of beer as well as other beverages. Polak's ambition was to create a base comprising a wide range of Polish alcohol and produce: local beer (over 100 types) and ciders, but also tinctures ${ }^{30}$. He opened a Library of Forms of Alcohol and a World Orangeade Drinking Competition, involving orangeade produced by "RONISZ", a firm established in Grochów in $1948^{31}$. It is here that one can notice an interesting novelty introduced by Polak: from the very beginning the clubhouse was decidedly inclusive and open to all milieus. It was enrooted in locality but, at the same time, upon a certain level Polishness (naturally, without a shade of xenophobia) functioned together with various crafted products made for local markets. Polak mentioned seeking precisely such brands and creating a network of suppliers of commodities that, as a rule, did not reach national distribution.

${ }^{30}$ An up-dated version of a description of the venue (June 2018) is as follows: "A culture clubhouse dedicated to Miron Białoszewski and Grochów. Place of social and art meetings. Space for unobvious activities. Literary meetings, indoor and outdoor cinema, exhibitions, concerts, dances. Debates held by aficionados-experts on Warsaw as well as about architecture and others. Art workshops. (Pro)social undertakings. Newspaper and book reading room, board games, Wi-Fi. Recycling and up-cycling design. Vegetarian food, bar, coffee and fair trade products.

We offer 200 brands of beer (inclding10 alcohol-free), 60 brands of vodka, spirits, tinctures and liqueurs, cider, wine, mead, alcohol-free beverages, kvass and podpiwek non-alcoholic beverages -90 per cent are Polish craft products by brewers, distillers, mead and cider makers, and lemonade and orangeade producers. Our specialities:

Juniper beer, carrot cake, vegan and vegetarian burgers, hummus, vegan lard, vegetable tarts, traditional Polish casseroles." https://www.facebook.com/pg/KlubKiciaKocia/about/, 17 January 2019.

31 "The «RONISZ» firm was established in 1948 and from that time steadily conducts its activity, specialising in the PRODUCTION OF WATERS AND BEVERAGES, the main product being TRADITIONAL ORANGEADE. During the first phase of its existence the enterprise was situated in 27/29 Zagójska Street - in 1980 it was transferred to 28 Podolska Street. Located on the edge of the OLSZYNKA GROCHOWSKA NATURE RESERVE, in a pure area uncontaminated by industry. It possesses its own water intake: «OLSZYNKA» SPRING WATER, the basis of all «RONISZ» products”, http:// www.olszynka.waw.pl., 6 December 2015. See also: Nazaruk 2014. 
The activity of the first Kicia Kocia, however, did not come down to merely satisfying culinary and gustatory tastes. It could be said that just as much or even more attention and energy were dedicated to cultural, social, and political efforts, thus opening a successive dimension of local quality. From the onset the clubhouse organised numerous social, cultural, and political meetings. It also became (co)host of assorted events by rendering its space available to other subjects pursuing their ideas, to mention the Szymon An-ski Foundation and the "discovery" in Grochów of a "forgotten" first kibbutz, which was supposed to teach farming and prepare its members for leaving for Palestine ${ }^{32}$. In the clubhouse numerous institutions, associations, and subjects could find a free-of charge place for the realisation of their conceptions of meetings. Kicia Kocia was also the site of discussions about local and supra-local problems, such as the boundaries of Grochów; debates also dealt with a postulate calling for changing the name: Praga-South (Praga Południe; a post-war name introduced together with renaming Praga to Praga-North/ Praga Północ), and a restoration of the pre-war historical name: Grochów.

After this practical description I would like to suggest several more theoretical comments. The place, according to the definition proposed by Heidegger, is rather closed, possesses an identity, and does not have a temporal dimension. Those aspects of the place were approached critically already by, i.a. Doreen Massey (1993), who stressed the necessity of taking into consideration temporality in thinking about the place. She outright claimed: "places are processes" ${ }^{33}$. Furthermore, Massey pointed to their identity polyvalence. The identity of a place is linked with the relations it establishes with the "outer world" 34 .

I believe that the same holds true particularly in the last example cited by me. This is an originally virtual place created by narratives and thanks to a supportive group, allies who "were bothered to" follow and back the history of its emergence on Facebook a special outside platform, which made it possible for Kicia Kocia to come into being in virtual space envisioned at the beginning. Although it is probably possible to speak about reference to things, as in the case of Heidegger, such things are at the same time underpinned and sometimes outright inseparable from the narrative. It is the latter, which together with things inserted place into time. It could be said that in this case the identity of the place is a project focused on the future, created together with references to the past; thus it is a special open project ${ }^{35}$. Upon certain occasions those narratives possess a creative power greater than things as such, although they could not exist with-

\footnotetext{
${ }^{32}$ Naturally, older residents of Grochów remembered the kibbutz perfectly; nonetheless, it did not exist in official memory, recorded or "inter-subjectivised". We described the story of the "discovery" of the kibbutz in the afore-mentioned book: Dudek and Sikora 2018, pp. 51-69.

${ }^{33}$ Massey 1993, p. 68.

34 "The identity of a place does not derive from some internalized history. It derives, in large part, precisely from the specificity of its interactions with «the outside»", Massey 1994, p. 169.

${ }^{35}$ Attention to the prospective character of identity was drawn by, i.a. Jean-Claude Kaufmann. Cf. Kaufmann 2011.
} 
out the latter. After all, places are created by people and the relations which they construct between themselves. I mentioned walks only marginally. (This is a separate important topic to which we devoted a chapter in the book ${ }^{36}$ ). They turned into spatial extensions, the "appendages" of place that encompassed the area of the district, sometimes aspiring to an even more extensive terrain. If, as I tried to suggest, places are truly connected with people creating them then the network of assorted subjects, sometimes located in various places (understood also metaphorically: institutions, associations, etc.) made it possible to "net" Kicia Kocia - to locate it precisely in space. In this instance I would postulate obliterating the strong place-space dichotomy. Kicia Kocia is actually a place-rhizome and in this respect one could say that the Heideggerian idea of place has been crossed. Today, feeling at home does not necessarily have to be linked with a moderately cohesive, from the point of view of identity, place. This could be a multi-dimensional place intertwined within an equally virtual system of relations.

In the present-day context - and this concerns particularly the cases of Grochów and Kicia Kocia, discussed here - it is also worth drawing attention to the political and civic aspect. The Auggie Wren cigar shop seems to have inserted itself quite successfully into the definition of a district mentioned in the introduction and formulated by Mayol: an enclave in which its residents can live basically without leaving it, a life that can manage "without politics" (apart from stories from a wider world, heard here and there and repeated), but successive examples already rub strongly against questions of citizenship and politics. Polak keeps a distance from politics comprehended as the necessity of speaking in favour of one of the sides of the present-day political scene and debate (or, in stronger terms: political dispute) in Poland; at the same time, by means of his attitude, accepted values, and discernible activism he speaks in favour of a civic stand, a conscious and thoughtful creation of his living place by referring to social values, and, in this case, also cultural ones. Feeling at home - both today and in the past - is thus constructed by things and narratives but also by engaged people and subjects, human and non-human authors, and with the assistance of relations created together with others, the problem being that such relations may assume new dimensions, also virtual ones.

Transl. Aleksandra Rodzinska-Chojnowska

\section{Bibliography}

Altay D. 2007, Urban Spaces Re-Defined in Daily Practices - "Minibar", Ankara [in:] Frers L., Meier L. (ed.), Encountering Urban Places: Visual and Material Performances in the City, Ashgate, Hampshire, pp. 63-80.

${ }^{36}$ Dudek, Sikora 2018, pp. 71-91. The motif of strolling also occurs in other chapters of the book. 
Barthes R. 1997, The Semiology and the Urban [in:] Leach N. (ed.), Rethinking Architecture. A Reader in Cultural Theory, Routledge, New York \& London, pp. 158-164.

Barthes R. 1975, The Pleasure of the Text, trans. by R. Miller, With a Note on the Text by Richard Howard, Hill and Wang, New York.

Berger J., Mohr J. 1982, Another Way of Telling, Pantheon Books, New York.

De Certeau M. 1984, The Practice of Everyday Life, trans. by S. Rendall, University of California Press, Berkeley.

Dudek K. J., Sikora S. 2018, Pustynia kulturalna? Siedem szkiców o dziataniu na Grochowie, Wydawnictwo Naukowe Katedra, Gdańsk.

Frąckowiak M., Luczys P. 2012, Na oponach albo kilka uwag o taktykach ucieczki pod dywan [in:]

Niewidzialne miasto, Krajewski M. (ed.), Fundacja Bęc Zmiana, Warszawa, pp. 279-297.

Hayden D. 1995, The Power of Place: Urban Landscapes as Public History, The MIT Press, Cambridge (Mass.).

Heidegger M. 2001, Poetry, Language, Thought, trans. and introduction by A. Hofstadter Harperperennial, New York.

Herzfeld M. 2004, Antropologia. Praktykowanie teorii w kulturze i spoteczeństwie, transl.

M.M. Piechaczek, Wydawnictwo Uniwersytetu Jagiellońskiego, Kraków.

Ingold T. 2011, Being Alive. Essays on Movement, Knowledge and Description, Routledge, London and New York.

Kaufmann J.-C. 2011, Identity and the New Nationalist Pronouncements, "International Review of Social Research" vol. 1, no. 2, June, pp. 1-13.

Massey D. 1993, Power-geometry and a progressive sense of place [in:] Bird J., Curtis B., Putnam T. et al. (ed.), Mapping the Futures. Local Cultures, Global Change, Routledge, London and New York.

Massey D. 1994, Space, Place, and Gender, University of Minnesota Press, Minneapolis.

Mayol P. 1998, Living [in:] de Certeau M., Giard L., Mayol P., The Practice of Everyday Life. Vol. 2. Living, Cooking, transl. T. J.Tomasik, University of Minnesota Press, Minneapolis.

Nazaruk I. 2014, Oranżada do podróży w czasie. Historia najstarszej istniejącej wytwórni wód gazowanych w Warszawie, "Gazeta Metro", 19 November 2014, http://metrowarszawa.gazeta. pl/metrowarszawa/1,1416 35,16993069,Oranzada_do_podrozy_w_czasie_Historia_najstarszej. html, 20 May 2016.

Sikora S. 2004, Fotografia. Między dokumentem a symbolem, Świat Literacki i Instytut Sztuki PAN, Izabelin.

Sikora S. 2012, Film i paradoksy wizualności. Praktykowanie antropologii, Wydawnictwo DiG, Warszawa.

Tuan Y.-F. 2001, Space and Place. The Perspective of Experience, University of Minnesota Press, Minneapolis London.

Zukin S. 2010, How Brooklyn Became Cool,w: S. Zukin, Naked city: the death and life of authentic urban places, Oxford University Press, Inc., Oxford i New York, s. 35-61 


\section{Filmography}

Auster P. and W. Wang 1995, Blue in the Face.

Auster P. and W. Wang 1995, Smoke.

Meyknecht S. 2010, Tobacco, Truths and Rummikub.

\section{Internet sources}

Synonim.Net, dictionary of synonyms for: "feeling at home", https://synonim.net/synonim/zado mowi\%C4\%87+si\%C4\%99, 15 November 2018.

Facebook Kicia Kocia:

https://www.facebook.com/pg/KlubKiciaKocia/about/, 17 January 2019.

https://www. facebook.com/KlubKiciaKocia/photos/a.479813125373254.108938.458666394

154594/482193858468514/?type=3\&permPage=1, 15 December 2015.

https://pl-pl.facebook.com/KlubKiciaKocia/photos/a.4 79813125373254.108938.4586663941 54594/498384776849422/?type=3, 15 December 2015.

https://www.facebook.com/KlubKiciaKocia/photos/a.4 79813125373254.108938.4586663941

54594/497360890285144/?type=38theatre, 15 December 2015.

Firm "Ronisz" Facebook, http://www.olszynka.waw.pl, 6 December 2015. 